\title{
Range Science Leadership Development in Kenya: A Continuing Legacy of Graduate Education
}

\author{
By S. K. Cherulyot, T. L. Thurow, and D. K. Too
}

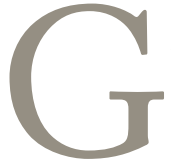

raduate education has long been supported by international development organizations as a tool to bolster technical capability within government agencies. This type of investment in domestic and international graduate education in most science and engineering fields has been declining for more than a decade. ${ }^{1}$ These trends contribute to the decrease in enrollment of international science and engineering graduate students attending US universities with temporary visas. $^{2}$

In addition to funding issues, development agencies must also surmount several other programmatic challenges when considering an investment in graduate education of international students. Impact assessments of the benefits that result from graduate education are inherently subjective because of the host of variables that influence career impact. Officers of development agencies have, therefore, tended to justify the substantial cost, time, and logistic support associated with graduate education based on their expert judgment that the long-term benefits are worth the cost. This "I know a good result when I see it" justification of graduate education programs is at odds with the current US government project-evaluation emphasis that focuses on quantifying impact (not to be confused with activity or output). Another programmatic concern is the perceived risk of loss of investment incurred by students who either do not finish their degree or who fail to return to their home country upon graduation.

The combinations of these considerations have contributed to development agencies scaling back investments in range science graduate-degree training for international students. This is unfortunate because the grassroots dividends of an investment in education are often among the most long-lasting of any type of development activity. This truism has long been recognized, as is reflected by the ancient Asian proverb "If you plan for 1 year, plant rice; if you plan for 20 years, plant trees; if you plan for 100 years, educate mankind." It is rare for an investment in an education project to be evaluated decades after the funding has ended. Without such a temporal perspective, development agencies are not equipped with the information needed to fully evaluate the benefits of education relative to the wide spectrum of other development goals. The objective of this article is to describe the role that the education component of the 19801985 Kiboko Range Research Expansion Project (KRREP) has had, and continues to have, on the development of the range profession in Kenya.

\section{History of the Range Profession in Kenya}

The early development of the range profession in Kenya follows a path that is roughly similar to many African countries. Pastoralists were the original managers of African rangelands, refining and applying an indigenous knowledge of grazed ecosystems. The rationales for the traditional rangeland-management perspectives were poorly understood by European colonialists and tended to be disregarded. The Kenyan colonial government began to focus on rangeland livestock-production constraints in 1946 when the African Land Development Board was assigned the task of administering rangelands. Most of this effort was related to disease control and water development, so the professionals involved in these activities tended to be expatriate veterinarians, animal scientists, or civil engineers. The African Land Development Board was disbanded when Kenya gained its independence in 1963 and was replaced by the establishment of a Ministry of Agriculture, within which 
was a Division of Range Management. There were no Kenyan citizens who had been formally trained in range management at that time; therefore, the initial rangeland management positions were staffed by expatriates provided by the US and UK governments and through United Nations Programs.

The need to develop range-management professionals to staff the research and extension needs within the Ministry of Agriculture prompted the creation, in 1965, of a 3-year diploma program in range management at Egerton College, Njoro, Kenya. In 1966, a 2-year certificate program was created at the Animal Health Industries Training Institute, Kabeti, Kenya. The faculties teaching the range courses for these programs were expatriates primarily from the United States, the United Kingdom, and Australia. Although these diploma and certificate programs were effective at educating the workforce needed to staff the lower levels of the government's range-management offices, there were few opportunities for the advanced education needed to cultivate indigenous leadership of range management in the government. This began to be addressed by the establishment of a Bachelor of Science (BS) degree in Range Management at Nairobi University, in 1980, staffed in part by the few Kenyans who had the opportunity in the previous decade to obtain a graduate degree in range management from the United States.

Similar patterns of rangeland administration and personnel development occurred throughout many African countries. A significant deviation from this generalized path of African range personnel development occurred in Kenya in
1980 when the US Agency for International Development (USAID) initiated a range program that had a component devoted to fostering graduate student research and education designed to create a leadership cadre of Kenyan range scientists. The Kiboko Range Research Expansion Project was implemented through Winrock International. In 1980, 21 students were selected based on their academic credentials to be sent to Texas A\&M University (17 students) or New Mexico State University (4 students). Twenty students had diplomas from Egerton College and were given the opportunity to take 1.5 years of undergraduate courses to obtain a BS and then immediately began their Master of Science (MS) degree coursework in Range Science; the other 1 student, who already had an MS degree, enrolled to pursue a $\mathrm{PhD}$. Most conducted their graduate research at the Kenya Agriculture Research Institute (KARI) Kiboko Research Station with funds that also provided for on-site supervision by the graduate committee chairs and expatriate US scientists that lived on the Kiboko Research Station. All 21 students succeeded in getting their graduate degrees within 2.5 to 4 years, all returned to Kenya after they graduated, and all pursued careers related to their range management education (Table 1 ).

Graduates of this program form a cornerstone of the range science research and education community in Kenya. In many cases, research that built upon their thesis projects was continued when the graduates returned to Kenya. This work has improved insight into vegetation ecology, livestock production, and watershed management in ways that have been mainstreamed into best management practices

Table 1. Current career status of the 21 students educated (1980-1985) as part of the range graduate-education program at Texas A\&M University and New Mexico State University

\begin{tabular}{|c|c|c|}
\hline \multicolumn{2}{|c|}{ Kenya Agriculture Research Institute } & \multirow{2}{*}{$\begin{array}{l}\text { Egerton University Faculty } \\
\text { S. Cheruiyot }\end{array}$} \\
\hline KARI Station Directors & & \\
\hline Name & Station Location & P. Kamau (retired as Department Head) \\
\hline P. Kibet & Kiboko & K. Maranga \\
\hline B. Woie (deceased) & Marsabit & D. Too (served as Department Head) \\
\hline KARI Scientists & & University of Nairobi Faculty \\
\hline A. Abdille (retired) & Kiboko & R. Kinuthia \\
\hline A. Ali & Mtwapa & J. Kinyamario \\
\hline F. Asambu (deceased) & Kiboko & N. Musimba \\
\hline D. Mbakaya & Kakamega & Office of President \\
\hline M. Mbui & Lanet & S. Shaabani (Arid Lands Management Advisor) \\
\hline W. Mnene & Kiboko & Kenyan Foreign Service Diplomat \\
\hline D. Musembi & Kiboko & N. Ndiangui (previously National Museum Scientist) \\
\hline M. Ojowi & Nairobi & Coastal Development Authority \\
\hline S. Onchoke (retired) & Kiboko & B. Mwandotto (administrator) \\
\hline
\end{tabular}


advocated by the government natural resource management agencies. These research results are also regularly used as classroom examples taught to the future generations of range managers being educated in Kenya. The KRREP project participants that elected to leave KARI and now work at either Egerton University or the University of Nairobi significantly bolstered the faculty numbers of both range programs thereby enabling both institutions to now offer $\mathrm{BS}$, MS, and $\mathrm{PhD}$ degrees in Range Management and Natural Resources Management (Fig. 1). Approximately 850 Kenyan students and 70 students from other African countries have received degrees in range management from these 2 universities since the KRREP participants began serving as faculty. In fact, it is rare to find a person working in range management in Kenya today who has not been educated by the graduates of the KRREP program.

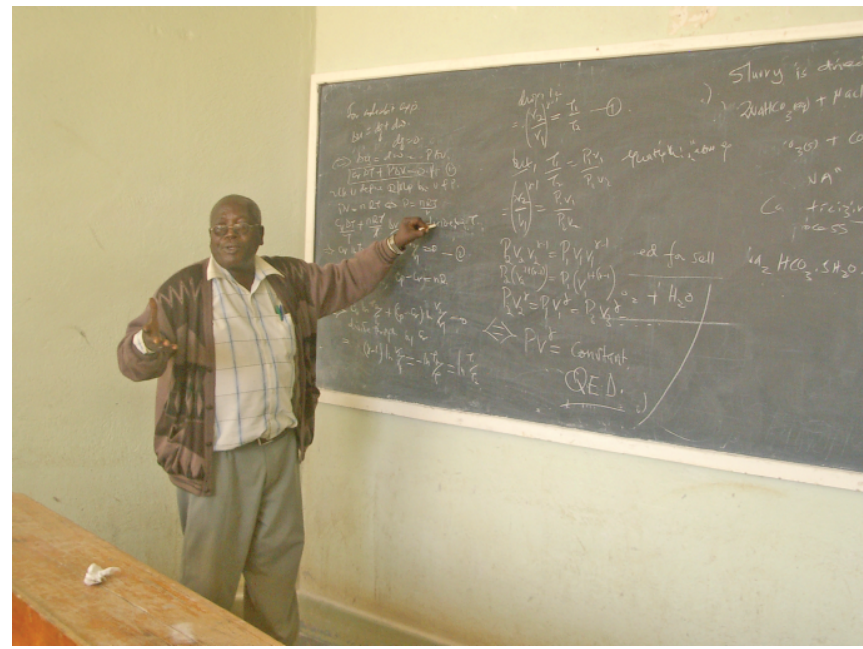

Figure 1. Seven of the graduate students supported by the Kiboko Range Research Expansion Project were employed soon after their return to Kenya as range-science faculty at Egerton University or the University of Nairobi (picture of Simeon Cheruiyot teaching at Egerton University). Their service continues to enable these universities to offer range-science curriculums that prepare students to meet the rangeland management employment needs of the region.

\section{Foreign Graduate-Student Education Considerations}

The KRREP graduate-student return rate and employment rate is very unusual. In general, a large percentage of foreign graduate students choose to not return to their home country after they have received a graduate degree in science or engineering from a US university. ${ }^{2}$ For example, of all foreign students studying in the US on a temporary visa who graduated with a doctorate in science or engineering in 1998, 68\% were still in the United States in 2003. There was a $61 \%$ stay rate for the subset coming from African countries. For agricultural-related fields, the stay rate for all foreign students receiving a doctorate was 49\%; the stay rate from agriculture students from Africa was 46\%. ${ }^{3}$ Scholars who come to the United States for a short course or who have earned master's degrees tend to have a higher return rate than those earning $\mathrm{PhDs}$, but still can represent a significant "brain drain" to the host country. ${ }^{4}$ The low return rate and the large cost and time commitment associated with the graduate education are often cited by development organizations as reasons why they are reluctant to invest in providing scholarships to US universities.

Return rates tend to be correlated with political and economic stability in the students' home countries, ${ }^{5}$ as well as the unemployment rate and perceived professional growth opportunities within the home country. ${ }^{6}$ Consequently, there is a wide divergence among return rates when the data are broken out by country. ${ }^{3}$ Therefore, the prospects for foreign graduate students returning to their home country upon graduation must be assessed case by case, rather than discussing graduate return rates as a global aggregate. The students educated through the KRREP program cite several factors that contribute to their perfect return and range-employment rate following their graduation. They graduated at a time when political and economic stability within Kenya was good. All the KRREP graduates were assured jobs at the Kiboko Research Station when they returned, where they could put their education to immediate use. Furthermore, there was a strong perceived need for graduate degree holders in range science at KARI, in the Ministries of Agriculture and Livestock, and at the Universities. Most of the KRREP students had conducted their graduate research in Kenya; consequently, they looked forward to continuing to pursue their research when they returned.

Another element that the KRREP graduates credit as part of their success was that they provided moral support to each other as they adjusted to life in the United States, in general, and to US academia, in particular. This experience supports current research regarding the benefits of learning support groups in aiding acclimation to college life and academic success. ${ }^{7}$ The students knew that they would be working with each other when they finished their degrees and returned to the Kiboko Research Station, thereby fostering the anticipation of a good community workplace. The personal bonds that developed through studying and living together while students and starting their careers together as returning scientists has proven to be a strong, lasting element that has helped the graduates network throughout the development of their careers.

The importance of this spectrum of factors being in place to encourage a high return rate and provide a foundation for the start of professional careers cannot be understated. This can be illustrated by the stark contrast in outcome of the range graduate-student education program associated with the USAID-funded Central Rangeland Development Project (CRDP). The CRDP took place in the neighboring country, Somalia, at about the same time as the KRREP. Between 1984 and 1987, the CRDP selected 12 students 
based on academic merit to begin graduate range-education programs. Like with the KRREP, the Somali students were assured employment with the CRDP when they returned. Like in Kenya, there was a strong demand for range science graduates throughout the Somali ministries and the national university. However, unlike the KRERP, there were significant differences. The political and economic stability of Somalia was precarious. Furthermore, the Somali students began their studies as individuals, dispersed in time and between 6 different US universities, thereby limiting the potential for formation of a learning support group of compatriots, a factor that was judged very important at a personal level by the Kenyan students. Graduate research funding was provided for only 3 of the 12 students to conduct research in Somalia, thereby limiting the inducement of being able to carry on with their established research when they returned. The result of the CRDP program was that 2 of the students complained of severe culture shock and dropped out after their first semester and immigrated to Canada. The remaining 10 students finished their degrees between 1986 and 1989. Of those, only 2 returned to Somalia, both taking positions with the national university (note that the Siad Barre government did not collapse until 1991; therefore, the anarchy of no central government that is the case today was not in place when the students completed their degrees).

\section{Summary}

The KRREP graduate-student program has had significant influence on the development of the range-science profession in Kenya over the past 2 decades. Relative to the usual low return rate of foreign graduate students educated in the United States, it is remarkable that $100 \%$ of the 21 KRREP graduates returned to Kenya to establish careers related to their degrees. The graduates attribute their high return rate to the combined factors of a stable economic and political condition in Kenya at the time of their graduation; guaranteed employment in their profession; anticipation of carrying on their research, which they had initiated in their country as part of their graduate program; and the anticipation of working with their colleagues with whom they had formed close bonds as part of an informal learning-support group throughout their graduate program. These factors should be strongly considered when a development project is designed that has a foreign education component. The extensive, continuing impact that the KRREP graduateeducation program has in Kenya is a strong testament to the value of such a development investment.

Authors are Lecturers, Department of Natural Resource Management, Egerton University, PO Box 536, Njoro, Kenya (Cheruiyot and Too); and Professor, Department of Rangeland Ecology and Watershed Management, University of Wyoming, Laramie, WY 82071, tthurow@uwyo.edu. Partial funding associated with the development and publication of this article was provided by the USAID Global Livestock Collaborative Research Support Program.

\section{References}

1. National Research Council (NRC). 2001. Trends in federal support of research and graduate education. Washington, DC: National Academies Press. 112 p.

2. National Research Council (NRC). 2005. Policy implications of international graduate students and postdoctoral scholars in the United States. Washington, DC: National Academies Press. 196 p.

3. FinN, M. G. 2005. Stay rates of foreign doctorate recipients from U.S. universities, 2003. Oak Ridge, TN: Oak Ridge Institute for Science and Education.

4. LI, C. 2005. Bridging minds across the Pacific: US-China educational exchanges 1978-2003. Lanham, MD: Lexington Books.

5. Bratsberg, B. 1995. The incidence of non-return among foreign students in the United States. Economics of Education Review 14(4):373-384.

6. Johnson, D. L. 2001. Relationship between stay rates of $\mathrm{PhD}$ recipients on temporary visas and relative economic conditions in country of origin. Oak Ridge, TN: Oak Ridge Institute for Science and Education.

7. Laufgraben, J. L. 2005. Learning communities. In: M. L. Upcraft, J. N. Gardner, and B. O. Barefoot [eds.]. Challenging and supporting the first-year student: A handbook for improving the first year of college. San Francisco, CA: Jossey-Bass Publishers. p. 371-389. 